\title{
Influence of Phosphorus Levels and Phosphorus Solubilizing Fungi on Yield and Nutrient Uptake by Wheat under Sub-Humid Region of Rajasthan, India
}

\author{
Amita Sharma, U. S. Rawat, and B. K. Yadav \\ Department of Agricultural Chemistry and Soil Science, Rajasthan College of Agriculture, \\ Maharana Pratap University of Agriculture and Technology, Udaipur 313001, India \\ Correspondence should be addressed to B. K. Yadav, bkyadav74@yahoo.co.in
}

Received 21 October 2011; Accepted 30 November 2011

Academic Editors: W. J. Rogers, C. Tsadilas, and W. P. Williams

Copyright () 2012 Amita Sharma et al. This is an open access article distributed under the Creative Commons Attribution License, which permits unrestricted use, distribution, and reproduction in any medium, provided the original work is properly cited.

The aim of the present study was to assess the influence of phosphorus levels and phosphorus solubilizing fungi on yield and nutrient uptake by wheat. The dry matter production by wheat at tillering, ear emergence, and harvest was significantly higher with $90 \mathrm{~kg} \mathrm{P}_{2} \mathrm{O}_{5} \mathrm{ha}^{-1}$ and was at par with $60 \mathrm{~kg} \mathrm{P}_{2} \mathrm{O}_{5} \mathrm{ha}^{-1}$. Application of Aspergillus awamori gave the highest dry matter accumulation at tillering, ear emergence, and harvest stage of crop growth. Increasing levels of phosphorus increased the grain and straw yield significantly up to $60 \mathrm{~kg} \mathrm{P}_{2} \mathrm{O}_{5} \mathrm{ha}^{-1}$ of wheat crop. However, the maximum grain and straw yield were obtained at $90 \mathrm{~kg} \mathrm{P}_{2} \mathrm{O}_{5} \mathrm{ha}^{-1}$, which was at par with $60 \mathrm{~kg} \mathrm{P}_{2} \mathrm{O}_{5} \mathrm{ha}^{-1}$. The combined application of $60 \mathrm{~kg} \mathrm{P}_{2} \mathrm{O}_{5}$ ha $^{-1}$ with A. awamori recorded significantly higher grain and straw yield. Increasing level of $\mathrm{P}$ application $\left(0\right.$ to $\left.90 \mathrm{~kg} \mathrm{P}_{2} \mathrm{O}_{5} \mathrm{ha}^{-1}\right)$ and inoculation with A. awamori and A. niger significantly increased uptake of $\mathrm{N}, \mathrm{P}$, and $\mathrm{K}$ in wheat at all stages of crop growth. The maximum nitrogen, phosphorus, and potassium uptake was recorded at harvest (grain and straw) followed by ear emergence and tillering when seeds were inoculated with Aspergillus awamori.

\section{Introduction}

Wheat (Triticum aestivum (L.)) is the second most important food grain crop in India ranking next to rice (Oryza sativa L.) contributing about $35 \%$ of the food grain production. India occupies second position next to China in the world with regard to area (27.7 million hectares) and production (77.6 million tonnes) of wheat. Rajasthan state has an area of 2.10 million hectares under wheat cultivation which is 7.95 per cent of the total cultivated area. The average productivity of wheat in the state is $31.75 \mathrm{qha}^{-1}$ [1]. This clearly indicates that in spite of considerable improvement in genetic potential of the crop, productivity is still very poor in the country $\left(28.06 \mathrm{q} \mathrm{ha}^{-1}\right)$ as well as in the state of Rajasthan. One of the reasons of low productivity is poor efficiency and low availability of phosphorus in soil due to high fixation. The high productivity of wheat can only be achieved by the adoption of suitable variety and improved agronomic practices with balanced and judicious use of chemical fertilizers in an integrated way.

Phosphorus is one of the most important major nutrients required for the growth and development of crop plants. It plays a vital role in virtually every plant process like photosynthesis, energy storage and transfer, stimulating root development and growth, giving plant rapid and vigorous start leading to better tillering in wheat, and encouraging earlier maturity and seed formation. It also has a significant role in sustaining and building up of soil fertility, particularly under intensive system of agriculture. But, Phosphorus is one of the most immobile, inaccessible, and unavailable nutrient present in the soil. Deficiency of soil phosphorus is one of the important chemical factors restricting plant growth in soils. Therefore, sufficient quantity of soluble form of phosphorus fertilizers is applied to achieve maximum plant productivity. However, the applied soluble forms of phosphatic fertilizers rapidly become unavailable to plants 
by conversion into inorganic $\mathrm{P}$ fractions that are fixed by chemical adsorption and precipitation. Similarly, organic P fractions are immobilized in soil organic matter [2].

Phosphorus solubilizing microorganisms (bacteria and fungi) enable $\mathrm{P}$ to become available for plant uptake after solubilization. Several soil bacteria, particularly those belonging to the genera Bacillus and Pseudomonas, and fungi belonging to the genera Aspergillus and Penicillium possess the ability to bring insoluble phosphates in soil into soluble forms by secreting organic acids such as formic, acetic, propionic, lactic, glycolic, fumaric, and succinic acids [3]. These acids lower the $\mathrm{pH}$ and bring about the dissolution of bound forms of phosphates. Venkateswarlu et al. [4] have reported that during the solubilization of rock phosphate by fungi, the $\mathrm{pH}$ of the culture was lowered from 7 to 3 . Some of the hydroxy acids may chelate with calcium and iron resulting in effective solubilization and utilization of phosphates [5]. Several workers reported yield increasing on wheat [6], onion [7], alfalfa [8], and soybean [9] through simple inoculation of Psolubilizing fungi (PSF). Kundu and Gaur [10] reported that the grain and straw yields of rice increased significantly due to inoculations. They further reported that the phosphate solubilizing microorganisms improved phosphorus uptake over control with and without chemical fertilizers. There is lack of information on the use of PSM for wheat under sub-humid region of Rajasthan, India. Therefore a field experiment was conducted to assess the role of phosphorus solubilizing fungi with different phosphorus levels on wheat yield and nutrient uptake in Inceptisols under sub-humid region of Rajasthan, India.

\section{Materials and Methods}

2.1. Experimental Site and Location. The experiment was conducted at the Instructional Farm, Rajasthan College of Agriculture, Udaipur, during rabi 2010-2011. The site is situated at South-Eastern part of Rajasthan at $24^{\circ} 35^{\prime} \mathrm{N}$ latitude and $74^{\circ} 42^{\prime} \mathrm{E}$ longitude at an altitude of $579.5 \mathrm{~m}$ above mean sea level. The region falls under agroclimatic zone of Rajasthan zone IV-A (sub-humid southern plain and arrival hills).

2.2. Climate and Weather Condition. The zone possesses typical subtropical climatic conditions characterized by mild winters and moderate summers associated with high relative humidity during the months of July to September. The average annual rainfall of the region is $637 \mathrm{~mm}$, most of which is received during the month of July to September. The mean weekly meteorological parameters recorded at agro-meteorological observatory, Rajasthan College of Agriculture, Udaipur, during cropping periods are presented in Figure 1. These observations reveal that maximum and minimum temperatures ranged from 23.3 to $36.4^{\circ} \mathrm{C}$ and 3.1 to $19.9^{\circ} \mathrm{C}$, respectively, while the maximum and minimum relative humidity ranged from 46 to 88.1 and 20.3 to 78 percent.

2.3. Seed Inoculation with Inoculums. Aspergillus strains were obtained from Department of Agricultural Chemistry and

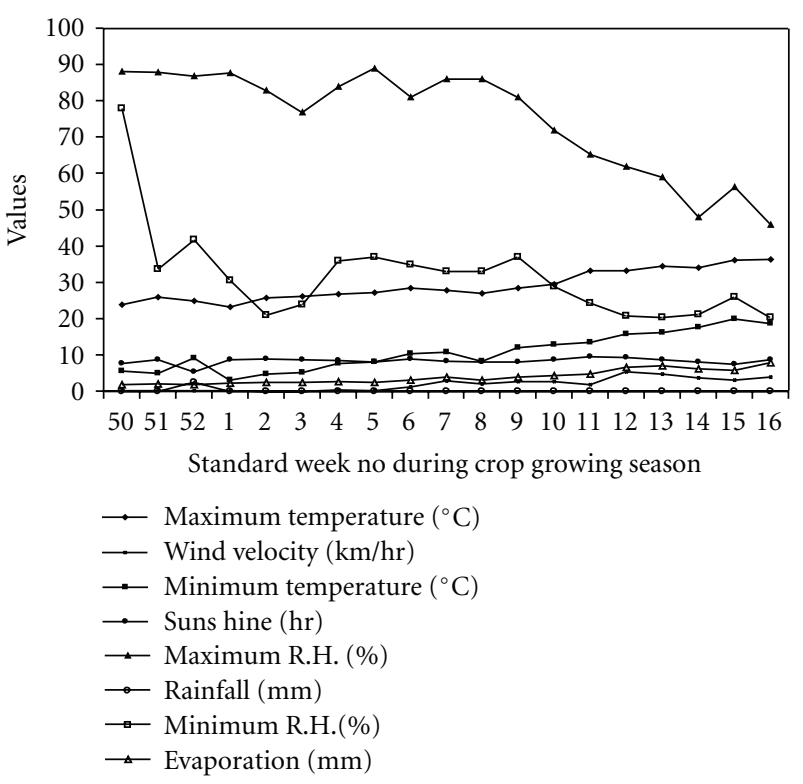

FIGURE 1: Climatic parameters of the experimental site during crop growing season.

Soil Science, Maharana Pratap University of Agriculture and Technology, Udaipur. These phosphorus solubilizing microorganisms were used to inoculate the seeds before sowing of wheat crop. The wheat seeds were surface sterilized with acidified $0.05 \% \mathrm{HgCl}_{2}$ for 2 minutes thereafter washed 5 to 6 times with sterilized deionized water which were then inoculated with Aspergillus strains in the slurry of carrier-based culture prepared in sterilized jaggery (25\% gur) solution and dried under shade prior to sowing. The required seeds which were to be treated with inoculums were thoroughly mixed with inoculums slurry in such a way that all the seeds were uniformly coated with inoculums according to the treatments.

2.4. Field Preparation and Cultivation Practices. In order to assess the physicochemical properties of the soil before commencement of the experiment, soil samples to the depth of $0-15 \mathrm{~cm}$ were drawn randomly from ten different places of the field and homogeneous composite sample was prepared. The soil sample was air dried under shade and then passed through $2.0 \mathrm{~mm}$ sieve and stored in labeled polythene bag before analysis. The physicochemical properties of the soil were presented in (Table 1) evident that the soil of the experimental field was sandy clay loam in texture, slightly alkaline in reaction, and calcareous in nature. The soil was medium in available nitrogen and phosphorus, while high in potassium.

The experimental field was ploughed by two crossharrowing followed by planking to obtain a good soil tilth. The seeds of wheat (Raj. 3077) were sown in plots $(5 \mathrm{~m} \times$ $2.5 \mathrm{~m}$ ) in a randomized block design with three replications with crop geometry $(23 \mathrm{~cm} \times 10 \mathrm{~cm})$. Recommended doses of $\mathrm{N}$ and $\mathrm{K}\left(120\right.$ and $\left.40 \mathrm{~kg} \mathrm{ha}^{-1}\right)$ were applied in all the plots including control. The sources used for applying nitrogen and phosphorus were urea and single super phosphate (SSP), 
TABle 1: Physicochemical properties of experimental soil before start of the experiment.

\begin{tabular}{lc}
\hline Soil properties & Contents \\
\hline Mechanical composition: & \\
Sand (\%) & 52.83 \\
Silt (\%) & 20.96 \\
Clay (\%) & 26.21 \\
Texture class & Sandy clay loam \\
Chemical properties: & \\
pH $(1: 2$, soil : water suspension) & 8.11 \\
EC [dSm & \\
Organic carbon $(1: 2$, soil $:$ water suspension $)]$ & 0.83 \\
Available nitrogen $\left(\mathrm{kg} \mathrm{ha}^{-1}\right)$ & 0.53 \\
Available phosphorus $\left(\mathrm{kg} \mathrm{ha}^{-1}\right)$ & 292.42 \\
Available potassium $\left(\mathrm{kg} \mathrm{ha}^{-1}\right)$ & 21.96 \\
\end{tabular}

respectively. Murate of potash (MOP) was used to supply K. Phosphorus application was made as per the treatment.

Half dose of nitrogen was applied as a basal dose and remaining half dose of nitrogen was applied, one month after sowing as top dressing. Full doses of phosphorous and potassium were applied at the time of sowing below the seed in furrows made with the help of hand hoe. Two manual weeding was done at one and two months after sowing to provide an ideal environment to the crop. First irrigation was given at the time of sowing; however, second, third, and fourth irrigation was given as the crop requirement and to maintain the optimum moisture level in the field.

2.5. Observations and Analysis. Soil $\mathrm{pH}$ and EC were determined using $1: 2.5$ soil: water suspension whereas soil particles, soil texture, organic carbon, available nitrogen, phosphorus, and potassium were determined following standard methods of analysis [11]. The wheat plant samples were collected at tillering, ear emergence, and harvest (grain and straw) stages from each plot and oven dried. The dried samples were finely ground and used for determination of $\mathrm{N}$, $\mathrm{P}$, and $\mathrm{K}$ content as per standard methods [11]. N, P and K uptakes were computed from the data of N, P, and K content and yield using the following formulae:

$$
\begin{aligned}
& \text { Macro nutrient uptake }\left(\mathrm{kg} \mathrm{ha}^{-1}\right) \\
& =\frac{\% \text { nutrient content in plant material } \times \text { Yield }\left(\mathrm{kg} \mathrm{ha}^{-1}\right)}{100} .
\end{aligned}
$$

2.6. Statistical Analysis. The experimental data were statistically analyzed for analysis of variance and test of significance through the procedure appropriate to the randomized block design. The critical differences were calculated whereas " $F$ " test was found significant as outlined by K. A. Gomez and A. A. Gomez [12].

\section{Results}

3.1. Dry Matte, Grain, and Straw Yield. Data presented in Table 2 on dry matter production revealed that the dry matter of wheat was significantly increased up to $60 \mathrm{~kg} \mathrm{P}_{2} \mathrm{O}_{5} \mathrm{ha}^{-1}$ level of phosphorus at all the stages of crop growth. However, the maximum dry matter production was observed at $90 \mathrm{~kg} \mathrm{P}_{2} \mathrm{O}_{5} \mathrm{ha}^{-1}$ but it was at par with $60 \mathrm{~kg} \mathrm{P}_{2} \mathrm{O}_{5} \mathrm{ha}^{-1}$. The significantly highest dry matter production was recorded under $60 \mathrm{~kg} \mathrm{P}_{2} \mathrm{O}_{5} \mathrm{ha}^{-1}$ which was higher by 28.85 and 45.23 per cent at tillering, 21.88 and 39.95 per cent at ear emergence, and 17.03 and 27.77 per cent at harvest as compared to control and $30 \mathrm{Kg} \mathrm{P}_{2} \mathrm{O}_{5} \mathrm{ha}^{-1}$ phosphorus level, respectively. The results also indicated that $\mathrm{P}$ response was significant up to $60 \mathrm{~kg} \mathrm{P}_{2} \mathrm{O}_{5} \mathrm{ha}^{-1}$ and further increase had no significant effect on dry matter production. Examination of data (Table 2) on Aspergillus inoculation revealed that the dry matter production was significantly increased with the inoculation of Aspergillus strains as compared to noninoculation by phosphorus solubilizing fungi. With the inoculums, the dry matter production increased from 4.21 to $5.94 \mathrm{q} \mathrm{ha}^{-1}, 26.71$ to $33.66 \mathrm{q} \mathrm{ha}^{-1}$, and 85.64 to $95.07 \mathrm{q} \mathrm{ha}^{-1}$ at tillering, ear emergence, and harvest stage, respectively. Maximum dry matter production obtained with the inoculation of $A$. awamori was found at par with $A$. niger at the three stages of crop growth.

Data presented in Table 2 illustrated the significant effect of application of phosphorus that increased the grain yield. However, the maximum grain yield was obtained at $90 \mathrm{~kg} \mathrm{P}_{2} \mathrm{O}_{5} \mathrm{ha}^{-1}\left(48.67 \mathrm{q} \mathrm{ha}^{-1}\right)$, which was at par with $60 \mathrm{~kg} \mathrm{P}_{2} \mathrm{O}_{5} \mathrm{ha}^{-1}\left(47.60 \mathrm{qha}^{-1}\right)$. The extent of increase recorded over control was of the order of 18.40, 29.52, and 32.43 per cent with the application of 30,60 , and $90 \mathrm{~kg} \mathrm{P}_{2} \mathrm{O}_{5} \mathrm{ha}^{-1}$, respectively. A perusal of data presented in Table 2 indicated that the phosphorus solubilizing microorganisms significantly increased grain yield as compared to noninoculation. When compared with the noninoculation, the extent of increase in grain yield with the inoculation with $A$. awamori and $A$. niger was of the order of 10.27 and 9.28 per cent, respectively. However, grain yield with $A$. awamori (45.75 $\mathrm{q} \mathrm{ha}^{-1}$ ) and $A$. niger (45.34 q2009ha ${ }^{-1}$ ) was found at par. It is apparent from the data presented in Table 2 that application of phosphorus levels up to $60 \mathrm{~kg} \mathrm{P}_{2} \mathrm{O}_{5} \mathrm{ha}^{-1}$ increased the straw yield significantly. The extent of increase due to application of 30 and $60 \mathrm{~kg} \mathrm{P}_{2} \mathrm{O}_{5} \mathrm{ha}^{-1}$ was of the order of 16.10 and 26.17 per cent, respectively, when compared with control. However, the maximum straw yield was obtained at $90 \mathrm{~kg} \mathrm{P}_{2} \mathrm{O}_{5} \mathrm{ha}^{-1}\left(52.80 \mathrm{qha}^{-1}\right)$, which was at par with that at $60 \mathrm{~kg} \mathrm{P}_{2} \mathrm{O}_{5} \mathrm{ha}^{-1}\left(51.01 \mathrm{q} \mathrm{ha}^{-1}\right)$ indicative of their equal effectiveness. A perusal of data presented in Table 2 also indicated that the phosphorus solubilizing microorganisms significantly increased straw yield compared to non inoculation. The inoculation of $A$. awamori and A. niger increased straw yield by 14.11 and 12.75 per cent, respectively, as compared with noninoculation, though, straw yields with A. awamori (50.37 $\mathrm{qha}^{-1}$ ) and A. niger (49.37 $\mathrm{q} \mathrm{ha}^{-1}$ ) were found nonsignificant.

3.2. Interaction Effect on Wheat Yield. The data related to the interaction effect of levels of phosphorus and phosphorus 
TABLE 2: Effect of levels of phosphorus and phosphorus solubilizing microorganisms on dry matter production and yield of wheat at different stages of growth.

\begin{tabular}{|c|c|c|c|c|c|}
\hline \multirow{2}{*}{$\begin{array}{l}\text { Treatment } \\
\text { Phosphorus levels }\end{array}$} & \multicolumn{3}{|c|}{ Dry matter production $\left(\mathrm{qha}^{-1}\right)$} & \multicolumn{2}{|c|}{ Yield $\left(\mathrm{qha}^{-1}\right)$} \\
\hline & Tillering & Ear emergence & Harvest & Grain & Straw \\
\hline Control & 4.09 & 24.63 & 77.18 & 36.75 & 40.43 \\
\hline $30 \mathrm{Kg} \mathrm{P}_{2} \mathrm{O}_{5} \mathrm{ha}^{-1}$ & 5.27 & 30.02 & 90.32 & 43.38 & 46.94 \\
\hline $60 \mathrm{Kg} \mathrm{P}_{2} \mathrm{O}_{5} \mathrm{ha}^{-1}$ & 5.94 & 34.47 & 98.61 & 47.60 & 51.01 \\
\hline $90 \mathrm{Kg} \mathrm{P}_{2} \mathrm{O}_{5} \mathrm{ha}^{-1}$ & 6.34 & 36.43 & 102.98 & 48.67 & 52.80 \\
\hline S.Em. \pm & 0.227 & 1.074 & 2.675 & 0.370 & 0.617 \\
\hline C.D. $(5 \%)$ & 0.665 & 3.151 & 7.845 & 1.085 & 1.811 \\
\hline \multicolumn{6}{|l|}{ Inoculum } \\
\hline Noninoculation & 4.21 & 26.71 & 85.64 & 41.49 & 44.14 \\
\hline Aspergillus awamori & 6.09 & 33.80 & 96.12 & 45.75 & 50.37 \\
\hline Aspergillus niger & 5.94 & 33.66 & 95.07 & 45.34 & 49.77 \\
\hline S.Em. \pm & 0.196 & 0.931 & 2.316 & 0.321 & 0.535 \\
\hline C.D. (5\%) & 0.576 & 2.729 & 6.794 & 0.940 & 1.568 \\
\hline
\end{tabular}

TABLE 3: Interaction effects of levels of phosphorus and phosphorus solubilizing microorganisms on grain and straw yield of wheat.

\begin{tabular}{|c|c|c|c|c|c|c|}
\hline \multirow{3}{*}{ Phosphorus levels } & \multicolumn{6}{|c|}{ Inoculum } \\
\hline & \multicolumn{3}{|c|}{ Grain yield $\left(\mathrm{qha}^{-1}\right)$} & \multicolumn{3}{|c|}{ Straw yield $\left(\mathrm{qha}^{-1}\right)$} \\
\hline & Noninoculation & A. awamori & A. niger & Noninoculation & A. awamori & A. niger \\
\hline Control & 32.95 & 39.06 & 38.24 & 34.98 & 44.21 & 42.09 \\
\hline $30 \mathrm{Kg} \mathrm{P}_{2} \mathrm{O}_{5} \mathrm{ha}^{-1}$ & 40.10 & 45.21 & 44.84 & 42.11 & 50.06 & 48.65 \\
\hline $60 \mathrm{Kg} \mathrm{P}_{2} \mathrm{O}_{5} \mathrm{ha}^{-1}$ & 47.85 & 49.17 & 48.78 & 49.65 & 52.87 & 54.00 \\
\hline $90 \mathrm{Kg} \mathrm{P}_{2} \mathrm{O}_{5} \mathrm{ha}^{-1}$ & 48.07 & 49.56 & 49.48 & 52.32 & 55.33 & 54.32 \\
\hline S.Em. \pm & & 0.641 & & & 1.069 & \\
\hline C.D. $(5 \%)$ & & 1.880 & & & 3.136 & \\
\hline
\end{tabular}

solubilizing microorganisms on grain and straw yield are presented in Table 3. Interaction effects of levels of phosphorus and phosphorus solubilizing micro-organism on grain and straw yield of wheat were significant. At each level of phosphorus the maximum grain and straw yields were observed with A. awamori inoculated seeds. Similarly, there was increase in grain and straw yield with the increasing doses of phosphorus up to $60 \mathrm{~kg} \mathrm{P}_{2} \mathrm{O}_{5} \mathrm{ha}^{-1}$ only in the seeds treated with inoculants. The maximum $\left(49.17 \mathrm{qha}^{-1}\right)$ grain yield was recorded with the application of $60 \mathrm{~kg} \mathrm{P}_{2} \mathrm{O}_{5} \mathrm{ha}^{-1}$ with $A$. awamori while minimum $\left(32.95 \mathrm{q} \mathrm{ha}^{-1}\right)$ was noted in control. Similarly, the maximum $\left(52.87 \mathrm{q} \mathrm{ha}^{-1}\right)$ straw yield was recorded with the application of $60 \mathrm{~kg} \mathrm{P}_{2} \mathrm{O}_{5} \mathrm{ha}^{-1}$ when seeds were inoculated with A. awamori. The data further revealed that increasing the $\mathrm{P}$ levels beyond $60 \mathrm{~kg} \mathrm{P}_{2} \mathrm{O}_{5} \mathrm{ha}^{-1}$ had no influence on wheat grain and straw yield even after inoculation with either A. awamori or A. niger.

3.3. Nutrients Uptake by Wheat. It is apparent from the data (Table 4) that the application of phosphorus up to $60 \mathrm{~kg} \mathrm{P}_{2} \mathrm{O}_{5}$ ha $^{-1}$ increased the uptake of nitrogen significantly at tillering, ear emergence, and harvest stage of wheat crop. However, the application of $90 \mathrm{~kg} \mathrm{P}_{2} \mathrm{O}_{5} \mathrm{ha}^{-1}$ was almost similar with $60 \mathrm{kgP}_{2} \mathrm{O}_{5} \mathrm{ha}^{-1}$. The increase recorded over control was of the order of $38.74,59.57$, and 71.87 per cent at tillering, $34.71,56.73$, and 66.73 per cent at ear emergence and $24.37,40.24$, and 46.39 per cent at harvest in grain while $32.82,52.86$, and 62.37 per cent increase was observed in straw with the application of 30,60 , and $90 \mathrm{~kg} \mathrm{P}_{2} \mathrm{O}_{5} \mathrm{ha}^{-1}$, respectively. The total nitrogen uptake by wheat crop was also significantly higher at $60 \mathrm{~kg} \mathrm{P}_{2} \mathrm{O}_{5} \mathrm{ha}^{-1}$ as compared to lower P level and control. The percent increase is 26.15 and 42.89. The data presented in Table 4 revealed importance of the seed inoculation with $A$. awamori and $A$. niger which significantly increased the uptake of nitrogen at tillering, ear emergence, and harvest stages of wheat growth. The seeds inoculated with $A$. awamori and A. niger, respectively, increased $\mathrm{N}$ uptake by 48.31 and 43.41 per cent at tillering stage, 34.34 and 33.13 per cent at ear emergence, and 17.52 and 14.88 per cent at harvest in grain while 32.02 and 29.18 per cent increase in $\mathrm{N}$ uptake was recorded in straw when compared with noninoculation of wheat seed. Total nitrogen uptake by wheat crop when inoculated with A. awamori and A. niger was more by 20.19 and 17.85 per cent, respectively, over noninoculation of seeds. The two strains were equally effective in enhancing $\mathrm{N}$-uptake.

Data presented in Table 5 showed that application of phosphorus at the rate of $60 \mathrm{~kg}_{2} \mathrm{O}_{5} \mathrm{ha}^{-1}$ brought out significant increase in phosphorus uptake at tillering, ear emergence, and harvest stage of crop growth. The extent of increase over control is $48.29,78.42$, and 94.35 per cent at tillering, 45.19, 79.31, and 92.96 per cent at ear emergence, and 
TABLE 4: Effect of levels of phosphorus and phosphorus solubilizing microorganisms on nitrogen uptake at different stages of wheat growth.

\begin{tabular}{|c|c|c|c|c|c|}
\hline \multirow{2}{*}{$\begin{array}{l}\text { Treatments } \\
\text { Phosphorus levels }\end{array}$} & \multirow[b]{2}{*}{ Tillering } & \multicolumn{4}{|c|}{ Nitrogen uptake $\left(\mathrm{kg} \mathrm{ha}^{-1}\right)$} \\
\hline & & Ear emergence & Harvest & By grain & By straw \\
\hline Control & 9.599 & 49.377 & 67.874 & 53.607 & 14.267 \\
\hline $30 \mathrm{Kg} \mathrm{P}_{2} \mathrm{O}_{5} \mathrm{ha}^{-1}$ & 13.318 & 66.514 & 85.623 & 66.673 & 18.949 \\
\hline $60 \mathrm{Kg} \mathrm{P}_{2} \mathrm{O}_{5} \mathrm{ha}^{-1}$ & 15.317 & 77.387 & 96.988 & 75.178 & 21.809 \\
\hline $90 \mathrm{Kg} \mathrm{P}_{2} \mathrm{O}_{5} \mathrm{ha}^{-1}$ & 16.498 & 82.325 & 101.552 & 78.476 & 23.165 \\
\hline S.Em. \pm & 0.6498 & 2.3276 & 1.556 & 1.275 & 0.4669 \\
\hline C.D. $(5 \%)$ & 1.9059 & 6.8267 & 4.565 & 3.3070 & 1.3692 \\
\hline \multicolumn{6}{|l|}{ Inoculum } \\
\hline Noninoculation & 10.479 & 56.250 & 78.213 & 61.968 & 16.245 \\
\hline Aspergillus awamori & 15.542 & 75.564 & 94.003 & 72.556 & 21.447 \\
\hline Aspergillus niger & 15.028 & 74.888 & 92.174 & 71.189 & 20.985 \\
\hline S.Em. \pm & 0.5268 & 2.0158 & 1.348 & 0.9765 & 0.4043 \\
\hline C.D. $(5 \%)$ & 1.6506 & 5.9121 & 3.953 & 2.8639 & 1.1858 \\
\hline
\end{tabular}

TABLE 5: Effect of levels of phosphorus and phosphorus solubilizing microorganisms on phosphorus uptake at different stages of wheat growth.

\begin{tabular}{|c|c|c|c|c|c|}
\hline \multirow{2}{*}{$\begin{array}{l}\text { Treatments } \\
\text { Phosphorus levels }\end{array}$} & \multirow[b]{2}{*}{ Tillering } & \multicolumn{4}{|c|}{ Phosphorus uptake $\left(\mathrm{kg} \mathrm{ha}^{-1}\right)$} \\
\hline & & Ear emergence & Harvest & By grain & By straw \\
\hline Control & 1.168 & 5.955 & 8.790 & 6.165 & 2.625 \\
\hline $30 \mathrm{Kg} \mathrm{P}_{2} \mathrm{O}_{5} \mathrm{ha}^{-1}$ & 1.732 & 8.646 & 12.385 & 8.522 & 3.863 \\
\hline $60 \mathrm{Kg} \mathrm{P}_{2} \mathrm{O}_{5} \mathrm{ha}^{-1}$ & 2.084 & 10.678 & 14.831 & 9.991 & 4.840 \\
\hline $90 \mathrm{Kg} \mathrm{P}_{2} \mathrm{O}_{5} \mathrm{ha}^{-1}$ & 2.270 & 11.492 & 15.472 & 10.484 & 5.087 \\
\hline S.Em. \pm & 0.0813 & 0.366 & 0.2589 & 0.1729 & 0.1043 \\
\hline C.D. $(5 \%)$ & 0.2383 & 1.0735 & 0.7593 & 0.5070 & 0.3059 \\
\hline \multicolumn{6}{|l|}{ Inoculum } \\
\hline Noninoculation & 1.318 & 7.191 & 11.462 & 7.875 & 3.587 \\
\hline Aspergillus awamori & 2.101 & 10.289 & 13.869 & 9.371 & 4.498 \\
\hline Aspergillus niger & 2.022 & 10.097 & 13.577 & 9.175 & 4.403 \\
\hline S.Em. \pm & 0.0704 & 0.317 & 0.2242 & 0.1497 & 0.0903 \\
\hline C.D. $(5 \%)$ & 0.2064 & 0.930 & 0.6576 & 0.4391 & 0.2649 \\
\hline
\end{tabular}

$38.23,62.14$, and 71.21 per cent in grain at harvest with the application of 30,60 , and $90 \mathrm{~kg} \mathrm{P}_{2} \mathrm{O}_{5} \mathrm{ha}^{-1}$, respectively. The increase in $\mathrm{P}$ uptake in straw was 47.16, 84.38, and 93.79 per cent. Although the highest $\mathrm{P}$ uptake was recorded with $90 \mathrm{~kg} \mathrm{P}_{2} \mathrm{O}_{5} \mathrm{ha}^{-1}$, it was nonsignificant with $60 \mathrm{~kg} \mathrm{P}_{2} \mathrm{O}_{5} \mathrm{ha}^{-1}$. In case of total $\mathrm{P}$ uptake, the per cent increase at $60 \mathrm{~kg} \mathrm{P}_{2} \mathrm{O}_{5} \mathrm{ha}^{-1}$ was 40.90 and 68.73 per cent higher when compared with overcontrol and $30 \mathrm{kgP}_{2} \mathrm{O}_{5} \mathrm{ha}^{-1}$, respectively. The data (Table 5 ) revealed that the seed inoculation with $A$. awamori and $A$. niger significantly increased the $\mathrm{P}$ uptake by wheat at tillering, ear emergence, and harvest stages of crop growth. The per cent increase due to seed inoculation by $A$. awamori and $A$. niger was of the order of 59.41 and 53.41 per cent at tillering, 43.08 and 40.41 per cent at ear emergence, and 19.00 and 16.51 per cent in grain at harvest, respectively, while the influence of these inoculants was 25.40 and 22.75 per cent in straw, respectively, due to $A$. awamori and $A$. niger. The total $\mathrm{P}$ uptake by wheat crop when inoculated with $A$. awamori and $A$. niger was 21.10 and 18.45 per cent higher over noninoculated seeds. The two inoculants
A. awamori and A. niger have similar effect in their influence on $\mathrm{P}$ uptake as a whole.

Data presented in Table 6 showed that application of phosphorus at $60 \mathrm{~kg} \mathrm{P}_{2} \mathrm{O}_{5} \mathrm{ha}^{-1}$ increased the potassium uptake significantly at tillering, ear emergence, and in grain and straw of wheat crop as compared to other P levels. The extent of increase recorded over control due to increasing $\mathrm{P}$ levels 30,60 , and $90 \mathrm{~kg} \mathrm{P}_{2} \mathrm{O}_{5} \mathrm{ha}^{-1}$, respectively was of the order of 42.33, 66.20, and 78.08 per cent at tillering, 28.36, 53.51, and 64.91 per cent at ear emergence and $30.88,49.88$, and 57.25 per cent in grain at harvest. Similarly, the increasing $\mathrm{P}$ doses also increased $\mathrm{K}$ uptake in wheat straw by 20.40, 37.17 , and 45.00 per cent. Although the highest $\mathrm{K}$ uptake was recorded with $90 \mathrm{~kg} \mathrm{P}_{2} \mathrm{O}_{5} \mathrm{ha}^{-1}$ and it was at par with that of $60 \mathrm{~kg} \mathrm{P}_{2} \mathrm{O}_{5} \mathrm{ha}^{-1}$, the per cent increase in total $\mathrm{K}$ uptake at $60 \mathrm{~kg} \mathrm{P}_{2} \mathrm{O}_{5} \mathrm{ha}^{-1}$ was 22.71 and 39.98 per cent higher over control and $30 \mathrm{~kg} \mathrm{P}_{2} \mathrm{O}_{5} \mathrm{ha}^{-1}$, respectively. The data on the effects of different inoculants of Aspergillus spices on uptake of potassium are presented in Table 6 which revealed that seed inoculation with $A$. awamori and $A$. niger significantly 
TABLE 6: Effect of levels of phosphorus and phosphorus solubilizing microorganisms on potassium uptake at different stages of wheat growth.

\begin{tabular}{|c|c|c|c|c|c|}
\hline \multirow{2}{*}{$\begin{array}{l}\text { Treatments } \\
\text { Phosphorus levels }\end{array}$} & \multirow[b]{2}{*}{ Tillering } & \multicolumn{4}{|c|}{ Potassium uptake $\left(\mathrm{kg} \mathrm{ha}^{-1}\right)$} \\
\hline & & Ear emergence & Harvest & By grain & By straw \\
\hline Control & 5.624 & 27.856 & 67.309 & 14.862 & 52.447 \\
\hline $30 \mathrm{Kg} \mathrm{P}_{2} \mathrm{O}_{5} \mathrm{ha}^{-1}$ & 8.005 & 35.757 & 82.596 & 19.451 & 63.145 \\
\hline $60 \mathrm{Kg} \mathrm{P}_{2} \mathrm{O}_{5} \mathrm{ha}^{-1}$ & 9.347 & 42.762 & 94.221 & 22.276 & 71.945 \\
\hline $90 \mathrm{Kg} \mathrm{P}_{2} \mathrm{O}_{5} \mathrm{ha}^{-1}$ & 10.015 & 45.938 & 101.619 & 23.371 & 76.045 \\
\hline S.Em. \pm & 0.352 & 1.519 & 1.741 & 0.376 & 1.462 \\
\hline C.D. $(5 \%)$ & 1.033 & 4.455 & 5.104 & 1.104 & 4.288 \\
\hline \multicolumn{6}{|l|}{ Inoculum } \\
\hline Noninoculation & 5.944 & 29.885 & 76.669 & 17.261 & 59.408 \\
\hline Aspergillus awamori & 9.521 & 42.309 & 92.001 & 21.620 & 78.380 \\
\hline Aspergillus niger & 9.277 & 42.041 & 90.640 & 21.236 & 69.404 \\
\hline S.Em. \pm & 0.305 & 1.316 & 1.507 & 0.326 & 1.266 \\
\hline C.D. $(5 \%)$ & 0.894 & 3.858 & 4.421 & 0.956 & 3.714 \\
\hline
\end{tabular}

TABLE 7: Interaction effects of levels of phosphorus and phosphorus solubilizing microorganisms on nitrogen and phosphorous uptake by wheat.

\begin{tabular}{|c|c|c|c|c|c|c|}
\hline \multirow[t]{3}{*}{ Phosphorus levels } & \multicolumn{3}{|c|}{ Nitrogen uptake $\left(\mathrm{kg} \mathrm{ha}^{-1}\right)$} & \multicolumn{3}{|c|}{ Phosphorus uptake $\left(\mathrm{kg} \mathrm{ha}^{-1}\right)$} \\
\hline & \multicolumn{6}{|c|}{ Inoculum } \\
\hline & Noninoculation & A. awamori & A. niger & Noninoculation & A. awamori & A. niger \\
\hline Control & 41.02 & 58.22 & 61.58 & 4.37 & 6.76 & 7.37 \\
\hline $30 \mathrm{Kg} \mathrm{P}_{2} \mathrm{O}_{5} \mathrm{ha}^{-1}$ & 59.63 & 72.09 & 68.30 & 7.53 & 9.32 & 8.72 \\
\hline $60 \mathrm{Kg} \mathrm{P}_{2} \mathrm{O}_{5} \mathrm{ha}^{-1}$ & 72.08 & 79.19 & 75.27 & 9.62 & 10.57 & 10.04 \\
\hline $90 \mathrm{Kg} \mathrm{P}_{2} \mathrm{O}_{5} \mathrm{ha}^{-1}$ & 75.14 & 80.73 & 80.61 & 9.99 & 10.84 & 10.82 \\
\hline S.Em. \pm & & 1.95 & & & 0.30 & \\
\hline C.D. $(5 \%)$ & & 5.72 & & & 0.88 & \\
\hline
\end{tabular}

increased the $\mathrm{K}$ uptake by wheat crop at tillering, ear emergence, and harvest stage of crop growth. The extent of increase recorded over control was of the order of 60.18 and 56.07 per cent at tillering, 41.57 and 40.68 per cent at ear emergence, and 25.25 and 23.03 per cent in grain at harvest and 31.93 and 16.83 per cent in straw as a consequence of the treatment receiving seed inoculation with $A$. awamori and $A$. niger, respectively. The total $\mathrm{K}$ uptake obtained was significantly higher 20.00 and 19.22 per cent at $60 \mathrm{~kg} \mathrm{P}_{2} \mathrm{O}_{5} \mathrm{ha}^{-1}$ as compared to control and $30 \mathrm{~kg} \mathrm{P}_{2} \mathrm{O}_{5} \mathrm{ha}^{-1}$. A. awamori and $A$. niger were nonsignificant in their influence on $\mathrm{K}$ uptake.

3.4. Interaction Effect on Nutrients Uptake by Wheat. The data related to the interaction effect of levels of phosphorus and phosphorus solubilizing microorganisms on nitrogen and phosphorus uptake by wheat are presented in Table 7. The interaction effect of levels of phosphorus and phosphorus solubilizing microorganisms on nitrogen uptake by wheat was found significant. The maximum nitrogen uptake was observed in A. awamori inoculated seeds at all the levels of $\mathrm{P}$ application. Similarly, there was increase in nitrogen uptake with the increasing doses of phosphorus up to $60 \mathrm{~kg} \mathrm{P}_{2} \mathrm{O}_{5} \mathrm{ha}^{-1}$ in the seeds treated with the two inoculants. The maximum $\left(79.192 \mathrm{~kg} \mathrm{ha}^{-1}\right)$ nitrogen uptake in grain was recorded with the application of $60 \mathrm{~kg} \mathrm{P}_{2} \mathrm{O}_{5} \mathrm{ha}^{-1}$ with A. awamori while minimum $\left(41.022 \mathrm{~kg} \mathrm{ha}^{-1}\right)$ was observed under control. The application of $90 \mathrm{~kg} \mathrm{P}_{2} \mathrm{O}_{5} \mathrm{ha}^{-1}$ with $A$. niger was found at par with $60 \mathrm{~kg} \mathrm{P}_{2} \mathrm{O}_{5} \mathrm{ha}^{-1}$ with $A$. awamori indicating superiority of $A$. awamori. The interaction effect of levels of phosphorus and phosphorus solubilizing microorganisms on phosphorus uptake of wheat was found to be significant. At each level of phosphorus, the maximum phosphorus uptake was observed in A. awamori inoculated seeds. Similarly, there was an increase in phosphorus uptake with the increasing doses of phosphorus up to $60 \mathrm{~kg} \mathrm{P}_{2} \mathrm{O}_{5} \mathrm{ha}^{-1}$ in the seeds treated with the two inoculants. The maximum $\left(10.57 \mathrm{~kg} \mathrm{ha}^{-1}\right)$ and minimum $\left(4.37 \mathrm{~kg} \mathrm{ha}^{-1}\right)$ phosphorus uptake in grain by wheat was, respectively, due to the application of $60 \mathrm{~kg} \mathrm{P}_{2} \mathrm{O}_{5} \mathrm{ha}^{-1}$ with A. awamori and control. The higher application of phosphorus $\left(90 \mathrm{~kg} \mathrm{P}_{2} \mathrm{O}_{5} \mathrm{ha}^{-1}\right)$ along with $A$. niger was found nonsignificant with the lower dose $\left(60 \mathrm{~kg} \mathrm{P}_{2} \mathrm{O}_{5} \mathrm{ha}^{-1}\right)$ when seeds were treated with $A$. awamori.

\section{Discussion}

4.1. Dry Matter, Grain, and Straw Yield. The data on the performance of phosphorus levels revealed a significant positive relation of grain and straw yield with the increased phosphorus application (Table 2). The improvement in growth and yield parameters might be due to the stimulating effect of phosphorus on plant process, namely, cell division and 
root elongation in merismatic tissues and constituent of ADP and ATP in plant. Similarly, the dry matter production also increased significantly with increasing phosphorus levels. The possible reason for increase in dry matter production could be correlated with the increased number of tillers. The increased numbers of tillers production ultimately enhanced the dry matter production. Such increase in tiller production could be the effect of increased root biomass through cell division and multiplication. The increased root biomass improved the nutrient uptake pattern by exploiting greater volume of soil which resulted in better physiological activity inside the plant system. Besides, phosphorus being the component of ATP-the energy currency in the metabolic activities-might have directly contributed to a larger photosynthetic and luxuriant vegetative growth. These observations confirm the findings of $\mathrm{Lu}$ and Barber [13] and Sharma and Parmar [14]. Further a large canopy development under the increased levels of phosphorus seems to have a greater absorption and utilization of radiant energy resulting in high dry matter accumulation by crop plants. The favorable effect of $\mathrm{P}$ application could be explained as less competition for the available metabolites in the grain due to relatively decreasing numbers of grains $\mathrm{ear}^{-1}$ at increasing level of phosphorus. The results corroborate the findings of Patil et al. [15]. Similar results were also reported by many workers [16-21]. The results showed that seed inoculation with A. awamori and A. niger significantly increased the dry matter and grain yield of wheat crop. A positive influence of fungus inoculation on plant biomass, straw yield, and grain yield was observed (Table 2). The higher levels of dry matter production and grain yield upon inoculation are mainly due to higher enzyme activities in the rhizosphere and better nutrient availability besides the production of the plant growth regulators by PSM. Venkateswarlu et al. [4] reported that production of organic acids such as lactic, glycolic, and succinic acids in the medium of $A$. niger can solubilize unavailable inorganic phosphates [22]. Strzelczyk et al. [23] reported that plant growth regulators such as ethylene and auxin, gibberellin, and cytokinin-like substances were produced by nonmycorrhizal fungi associated with the roots of forest trees. Higher enzyme activity in soils indicated the potential of soil to affect the biochemical transformations necessary for the maintenance of soil fertility [24]. Similar findings were also reported by Sundara et al. [25], Singh and Rai [26], Afzal et al. [27], Jakhar et al. [28], Tarafdar and Gharu [29], Yadav and Tarafdar [30], Afzal and Bano [31], Panda and Rai [32], Yadav et al. [33], Azad et al. [21], Yadav and Tarafdar [34], and Yadav and Tarafdar [35].

4.2. Nutrients Uptake by Wheat. Significant increasing trends of nitrogen uptake by wheat were recorded with increasing levels of phosphorus up to $60 \mathrm{~kg} \mathrm{P}_{2} \mathrm{O}_{5} \mathrm{ha}^{-1}$ (Table 4). It was owing to possible interaction of nitrogen and applied phosphorus. As phosphorus fertilization augmented the higher productivity, it resulted in higher nitrogen accumulation. Similar results have been also reported by Singh et al. [19], Bhunia et al. [20], and Suri et al. [36]. A significant increasing trend of phosphorus uptake by grain and straw was recorded with increasing levels of phosphorus up to $60 \mathrm{~kg} \mathrm{P}_{2} \mathrm{O}_{5} \mathrm{ha}^{-1}$
(Table 5). This may be due to increased concentration of phosphorus in soil solution with increasing phosphorus application. The increase in $\mathrm{P}$ uptake may be attributed to higher $\mathrm{P}$ content as well as grain and straw yields with higher dose of P. The results are in conformity with the findings of Choudhary et al. [37]. Unlike the dry matter production, $\mathrm{P}$ concentration tended to be lower with rise in soil fertility, which may be due to relatively higher rates of dry matter accumulation compared to $\mathrm{P}$ uptake rate. Like the dry matter production, the total $\mathrm{P}$ uptake by wheat plants was also affected significantly by the native $\mathrm{P}$ and graded levels of applied P. Findings of the present study corroborate with results as reported by Singh et al. [19] Bhunia et al. [20], Han et al. [38], Jain and Dahama [39], Setia and Sharma [40], Panda and Rai [32], Azad et al. [21], and Kizilgoz and Sakin [41]. Increased potassium uptake by grain and straw might be due to the synergistic effect between phosphorus and potassium and better root growth. The increased uptake of this nutrient might have increased the potassium content in grain and straw. The potassium uptake was significantly enhanced with the application of $60 \mathrm{~kg} \mathrm{P}_{2} \mathrm{O}_{5} \mathrm{ha}^{-1}$ in grain and straw (Table 6). Since nutrient uptake is a function of their content in grain and straw and yield of crop, the increase in these parameters due to phosphorus application leads to an increase in the uptake of this nutrient. Similar results have also been reported by Singh et al. [19] Bhunia et al. [20], and Suri et al. [36].

Results presented in Table 4 showed that the uptake of nitrogen at tillering, ear emergence, and in grain and straw at harvest increased with inoculation of Aspergillus strains. The inoculation with phosphate solubilizing microorganisms also significantly increased the uptake of nitrogen which may be due to enhanced availability and uptake of phosphorus, which is known to be positively related with nitrogen uptake. Increased plant $\mathrm{N}$ content could be higher availability of $\mathrm{N}$ due to mineralization of organic $\mathrm{N}$ [42]. The total nitrogen uptake increased considerably due to the improvement in symbiotic $\mathrm{N}_{2}$ fixation. Further, it is well established that if the P nutrition of plants is improved, either through fertilization or biological means, symbiotic $\mathrm{N}_{2}$-fixation and the plant $\mathrm{N}$ contents are improved. These findings are in confirmation to the earlier reports of Tarafdar et al. [43], Singh et al. [19], Han et al. [38], and Yadav et al. [33]. It is evident from the data presented in Table 5 that seed inoculation with different phosphorus solubilizing microorganism significantly increased the $\mathrm{P}$ uptake of wheat at tillering, ear emergence, and harvest stage of wheat crop. The inoculation with phosphate-solubilizing microorganisms also enhanced the phosphorus uptake to a level of significance compared to uninoculated plots due to microbial activity that could have resulted in quantitative and qualitative alterations of root exudates composition due to the degradation of exudate compounds and the release of microbial metabolites [44]. Microbial activity is a central factor in the soil organic P cycle and affects the transformations of inorganic P [45]. Influence of $\mathrm{P}$ status on uptake efficiency could be attributed to the change in root parameters of the plant. There were differences among Aspergillus strains in their ability to stimulate plant growth and nutrient uptake in wheat. Similar 
observations have been observed for mung and clusterbean [43]. There may be specific interaction between the plant species and Aspergillus strains. These results are in line with those reported by Tarafdar et al. [43], Tarafdar and Gharu [29], Han et al. [38], Yadav and Tarafdar [30], Afzal and Bano [31], Khan et al. [46], Yadav et al. [33], Yadav and Tarafdar [34], and Yadav and Tarafdar [35]. The results (Table 6) showed that seed inoculation with $A$. awamori and A. niger significantly increased the content and uptake of potassium of wheat crop. A significant increase in $\mathrm{K}$ concentration only with the inoculation of $A$. awamori indicates the ability of this fungus to react with K-minerals. The increased availability of soil K may be attributed to direct supply of soil $\mathrm{K}$ and to solubilizing $\mathrm{K}$ from $\mathrm{K}$-bearing minerals through organic acids released that could have increased the $\mathrm{K}$ content in plants. The beneficial effects on nutrient uptake could also be related to the improvement in soil physical properties [47]. Similar findings were also reported by Tarafdar et al. [43], Han et al. [38] and Yadav et al. [33].

\section{References}

[1] GOI, Economic survey 2008-09, Government of India, Department of Economic Affairs, Economics Division, New Delhi, India, 2009.

[2] S. K. Sanyal and S. K. De Datta, "Chemistry of phosphorus transformation in soil," Advances in Soil Sciences, vol. 16, pp. 1-120, 1991.

[3] M. Rashid, S. Khalil, N. Ayub, S. Alam, and F. Latif, "Organic acids production and phosphate solubilization by phosphate solubilizing microorganisms (PSM) under in vitro conditions," Pakistan Journal of Biological Sciences, vol. 7, pp. 187196, 2004.

[4] B. Venkateswarlu, A. V. Rao, and P. Raina, "Evaluation of phosphorus solubilization by microorganisms isolated from arid soils," Indian Society of Soil Science, vol. 32, pp. 273-277, 1984.

[5] B. S. Kundu, K. Nehra, R. Yadav, and M. Tomar, "Biodiversity of phosphate solubilizing bacteria in rhizosphere of chickpea, mustard and wheat grown in different regions of Haryana," Indian Journal of Microbiology, vol. 49, no. 2, pp. 120-127, 2009.

[6] M. A. Whitelaw, T. J. Harden, and G. L. Bender, "Plant growth promotion of wheat inoculated with Penicillium radicum sp. nov," Australian Journal of Soil Research, vol. 35, no. 2, pp. 291300, 1997.

[7] N. Vassilev, M. Toro, M. Vassileva, R. Azcon, and J. M. Barea, "Rock phosphate solubilization by immobilized cells of Enterobacter sp. in fermentation and soil conditions," Bioresource Technology, vol. 61, no. 1, pp. 29-32, 1997.

[8] R. Rodríguez, N. Vassilev, and R. Azcón, "Increases in growth and nutrient uptake of alfalfa grown in soil amended with microbially-treated sugar beet waste," Applied Soil Ecology, vol. 11, no. 1, pp. 9-15, 1999.

[9] M. H. Abd-Alla and S. A. Omar, "Survival of Rhizobia/Bradyrhizobia and a rock-phosphate-solubilizing fungus Aspergillus niger on various carriers from some agro-industrial wastes and their effects on nodulation and growth of faba bean and soybean," Journal of Plant Nutrition, vol. 24, no. 2, pp. 261272, 2001.

[10] B. S. Kundu and A. C. Gaur, "Rice response to inoculation with N2-fixing and P-solubilizing microorganisms," Plant and Soil, vol. 79, no. 2, pp. 227-234, 1984.
[11] D. Singh, P. K. Chhonkar, and B. S. Dwivedi, Manual on Soil, Plant and Water Analysis, Westville Publishing House, New Delhi, India, 2005.

[12] K. A. Gomez and A. A. Gomez, Statistical Procedures for Agricultural Research, John Wiley \& Sons, New York, NY, USA, 1984.

[13] N. Lu and S. A. Barber, "Phosphorus uptake rate and growth characteristics of wheat roots," Journal of Plant Nutrition, vol. 8, pp. 449-456, 1995.

[14] P. K. Sharma and D. K. Parmar, "The effect of phosphorus and mulching on the efficiency of phosphorus use and productivity of wheat grown on a mountain Alfisol in the Western Himalayas," Soil Use and Management, vol. 14, no. 1, pp. 2529, 1998.

[15] N. M. Patil, R. B. Patil, and K. K. Patil, "Reponse of wheat (Triticum aestivum) varities to nitrogen and phosphorus," Indian Journal of Agronomy, vol. 36, pp. 225-256, 1991.

[16] B. S. Brar, N. S. Dhillon, and H. S. Chhina, "Response of wheat (Triticum aestivum) to applied phosphate in some flood plain soils of Punjab," Indian Journal of Agricultural Sciences, vol. 73, no. 10, pp. 564-566, 2003.

[17] B. B. Panda, R. K. Rai, and A. Das, "Effect of phosphorus levels and biofertilizers on grain Yield and microbial population in the rhizosphere of wheat (Triticum aestivum L.)," Annals of Agricultural Research, vol. 24, pp. 631-633, 2003.

[18] A. S. Jat, R. C. Dadheech, B. Ram, and M. L. Jat, "Effect of herbicides, phosphorus and phosphate solubilizers on growth, yield and weed-control efficiency of wheat (Triticum aestivum) in Central Plateau and Hills Zone of India," Indian Journal of Agronomy, vol. 49, no. 1, pp. 53-56, 2004.

[19] V. Singh, R. S. Paudia, and K. L. Totawat, "Effect of phosphorus and zinc nutrition of wheat (Triticum aestivum) in soils of sub-humid southern plains of Rajasthan," Indian Journal of Agronomy, vol. 49, no. 1, pp. 46-48, 2004.

[20] S. R. Bhunia, R. P. S. Chauhan, B. S. Yadav, and A. S. Bhati, "Effect of phosphorus, irrigation and Rhizobium on productivity, water use and nutrient uptake in fenugreek (Trigonella foenum-graecum)," Indian Journal of Agronomy, vol. 51, no. 3, pp. 239-241, 2006.

[21] V. B. Azad, B. S. Bali, and A. A. S. Saha, "Effect of phosphorus levels and biofertilizers on yield, P-uptake and economics of wheat (Triticum aestivum)," Environment and Ecology, vol. 28, pp. 534-537, 2010.

[22] P. E. A. Asea, R. M. N. Kucey, and J. W. B. Stewart, "Inorganic phosphatise solubilisation by two Penicillium species in solution culture and soil," Soil Biology \& Biochemistry, vol. 20, pp. 459-464, 1988.

[23] E. Strzelczyk, A. Pokojska, M. Kampert, L. Michalski, and S. Kowalski, "Production of plant growth regulators by nonmycorrhizal fungi associated with the roots of forest trees," in Interaction between Microorganism and Plants in Soil, V. Vancura and F. Kunc, Eds., pp. 213-222, Elsevier, Amsterdam, The Netherlands, 1989.

[24] A. V. Rao, K. Bala, and J. C. Tarafdar, "Dehydrogenase and phosphatase activities in soil as influenced by the growth of arid-land crops," The Journal of Agricultural Science, vol. 115, pp. 221-225, 1990.

[25] B. Sundara, V. Natarajan, and K. Hari, "Influence of phosphorus solubilizing bacteria on the changes in soil available phosphorus and sugarcane and sugar yields," Field Crops Research, vol. 77, no. 1, pp. 43-49, 2002.

[26] T. Singh and R. K. Rai, "Growth parameters, nutrient uptake and soil fertility under wheat (Triticum aestivum) as influenced by levels of phosphorus and phosphate-solubilizing 
micro-organisms," Indian Journal of Agronomy, vol. 48, no. 3, pp. 182-185, 2003.

[27] A. Afzal, M. Ashraf, S. A. Asad, and M. Farooq, "Effect of phosphate solubilizing microorganisms on phosphorus uptake, yield and yield traits of wheat (Triticum aestivum) in rainfed area," International Journal of Agriculture and Biology, vol. 7, pp. 207-209, 2005.

[28] P. Jakhar, J. Singh, and R. K. Nanwal, "Effect of planting methods, biofertilizers and nitrogen levels on growth, yield and economics of wheat (Triticum aestivum L.)," Annals of Agricultural Research, vol. 26, pp. 603-605, 2005.

[29] J. C. Tarafdar and A. Gharu, "Mobilization of organic and poorly soluble phosphates by Chaetomium globosum," Applied Soil Ecology, vol. 32, no. 3, pp. 273-283, 2006.

[30] B. K. Yadav and J. C. Tarafdar, "Ability of Emericella rugulosa to mobilize unavailable $\mathrm{P}$ compounds during Pearl millet [Pennisetum glaucum (L.) R. Br.] crop under arid condition," Indian Journal of Microbiology, vol. 47, no. 1, pp. 57-63, 2007.

[31] A. Afzal and A. Bano, "Rhizobium and phosphate solubilizing bacteria improve the yield and phosphorus uptake in wheat (Triticum aestivum)," International Journal of Agriculture and Biology, vol. 10, no. 1, pp. 85-88, 2008.

[32] B. B. Panda and R. K. Rai, "Effect of phosphorus levels and biofertilizers on phosphorus utilization in wheat (Triticum aestivum L.) using ${ }^{32} \mathrm{P}$ as a tracer," Journal of Tropical Agriculture, vol. 26, pp. 1-2, 2008.

[33] B. K. Yadav, R. Niwas, R. S. Yadav, and J. C. Tarafdar, "Effect of Chaetomium globosum inoculation and organic matter on phosphorus mobilization in soil and yield of clusterbean," Annals of Arid Zone, vol. 48, no. 1, pp. 41-44, 2009.

[34] B. K. Yadav and J. C. Tarafdar, "Studies on phosphatase activity and clusterbean production as influenced by the P mobilizing organism Emericella rugulosa," Legume Research, vol. 33, no. 2, pp. 114-118, 2010.

[35] B. K. Yadav and J. C. Tarafdar, "Penicillium purpurogenum, unique p mobilizers in arid agro-ecosystems," Arid Land Research and Management, vol. 25, no. 1, pp. 87-99, 2011.

[36] V. K. Suri, G. Chander, A. K. Choudhary, and T. S. Verma, "Co-inoculation of VA-mycorrhizae (VAM) and phosphate solubilizing bacteria (PSB) in enhancing phosphorus supply to wheat in a typic Hapludalf," Crop Research, vol. 31, no. 3, pp. 357-361, 2006.

[37] N. R. Choudhary, A. K. Vyas, and A. K. Singh, "Growth and nutritent uptake in wheat as influenced by nitrogen, phosphorus and zinc fertilization," Annals of Agricultural Research, vol. 18, pp. 365-366, 1997.

[38] H. S. Han, Supanjani, and K. D. Lee, "Effect of co-inoculation with phosphate and potassium solubilizing bacteria on mineral uptake and growth of pepper and cucumber," Plant, Soil and Environment, vol. 52, no. 3, pp. 130-136, 2006.

[39] N. K. Jain and A. K. Dahama, "Direct and residual effects of phosphorus and zinc fertilization on productivity of wheat (Triticum aestivum)-pearl millet (Pennisetum glaucum) cropping system," Indian Journal of Agronomy, vol. 51, no. 3, pp. 165-169, 2006.

[40] R. K. Setia and K. N. Sharma, "Dynamics of forms of inorganic phosphorus during wheat growth in a continuous Maizewheat cropping systems," Indian Society of Soil Science, vol. 55, pp. 139-146, 2007.

[41] I. Kizilgoz and E. Sakin, "The effects of increased phosphorus application on shoot dry matter, shoot $\mathrm{P}$ and $\mathrm{Zn}$ concentrations in wheat (Triticum durum L.) and maize (Zea mays L.) grown in a calcareous soil," African Journal of Biotechnology, vol. 9, no. 36, pp. 5893-5896, 2010.
[42] G. B. Reddy and S. Reddy, "Effect of organic manures and nitrogen levels in soil available nutrients status in maize-soybean cropping systems," Indian Society of Soil Science, vol. 51, pp. 78-80, 1998.

[43] J. C. Tarafdar, A. V. Rao, and Praveen-Kumar, "Role of phosphatase-producing fungi on the growth and nutrition of clusterbean (Cyamopsis tetragonoloba (L.) Taub.)," Journal of Arid Environments, vol. 29, no. 3, pp. 331-337, 1995.

[44] G. Neumann and V. Römheld, "The release of root exudates as affected by the plant's physiological status," in The Rhizosphere, Biochemistry and Organic Substances at the Soil-Plant Interface, R. Pinton, Z. Varanani, and P. Nannipieri, Eds., pp. 41-93, Marcel Dekker, New York, NY, USA, 2000.

[45] R. M. N. Kucey, H. H. Janzen, and M. E. Leggett, "Microbially mediated increases in plant-available phosphorus," Advances in Agronomy, vol. 42, pp. 199-228, 1989.

[46] A. A. Khan, G. Jilani, M. S. Akhtar, S. M. S. Naqvi, and M. Rasheed, "Phosphorus solubilizing bacteria: occurrence, mechanisms and their role in crop production," International Journal of Biological Sciences, vol. 1, pp. 48-58, 2009.

[47] K. K. Nambiar and I. P. Abrol, "Long-term fertilizer experiments in India-A overview," Fertilizer News, vol. 34, pp. 1120, 1989. 


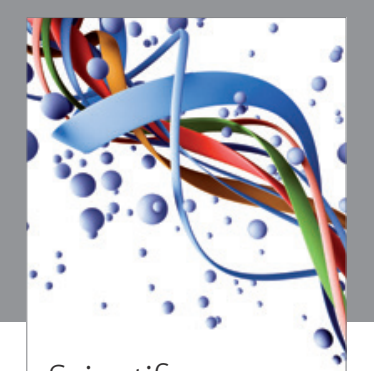

Scientifica
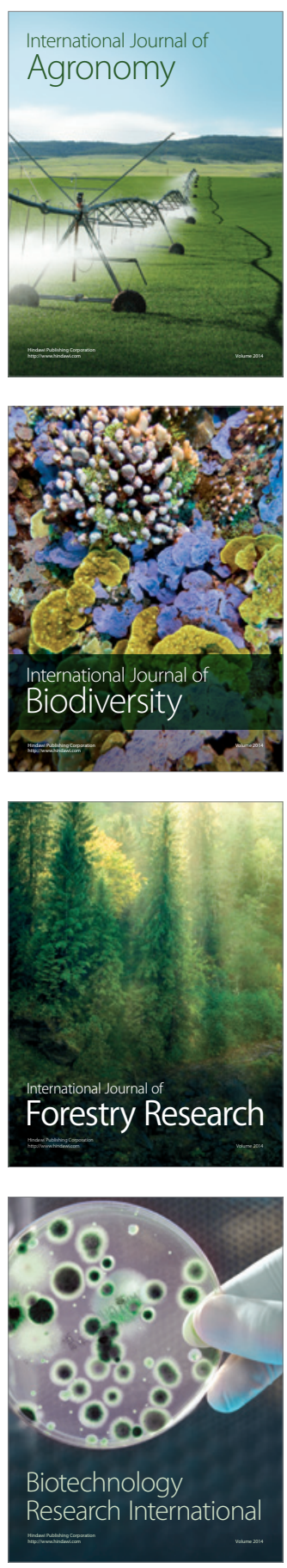
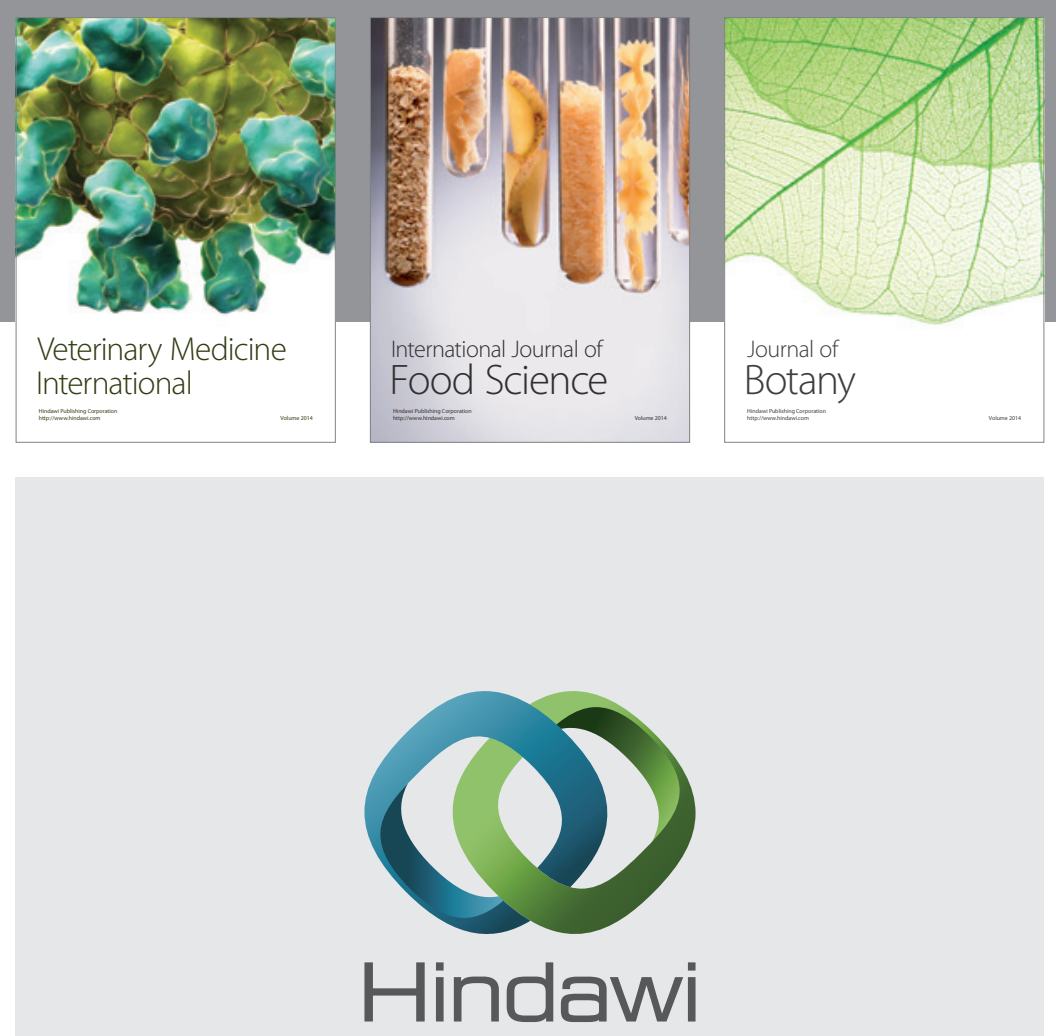

Submit your manuscripts at

http://www.hindawi.com
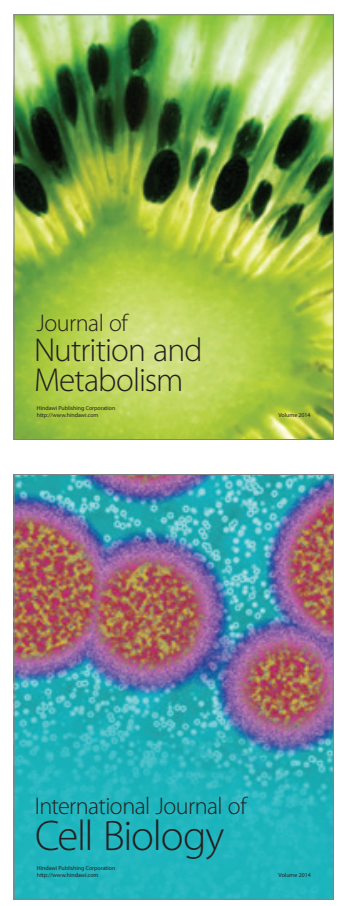
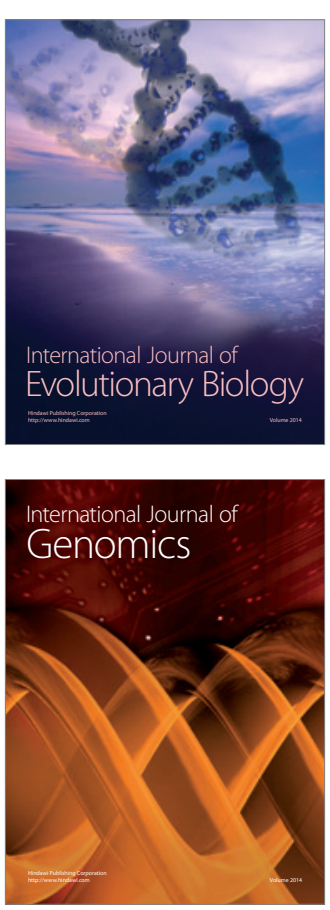
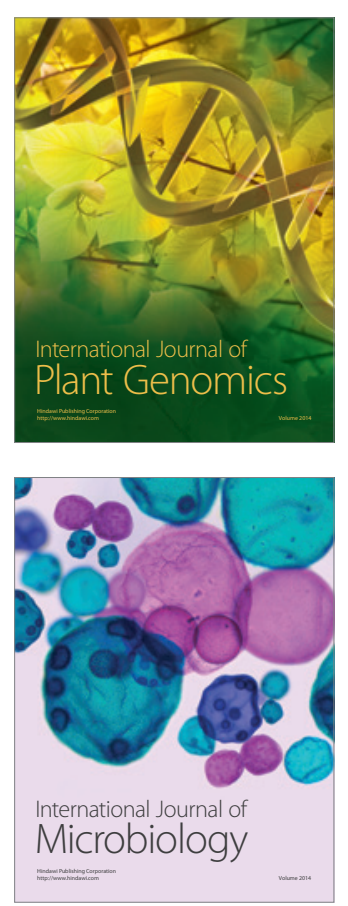

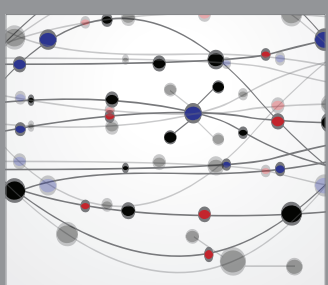

The Scientific World Journal
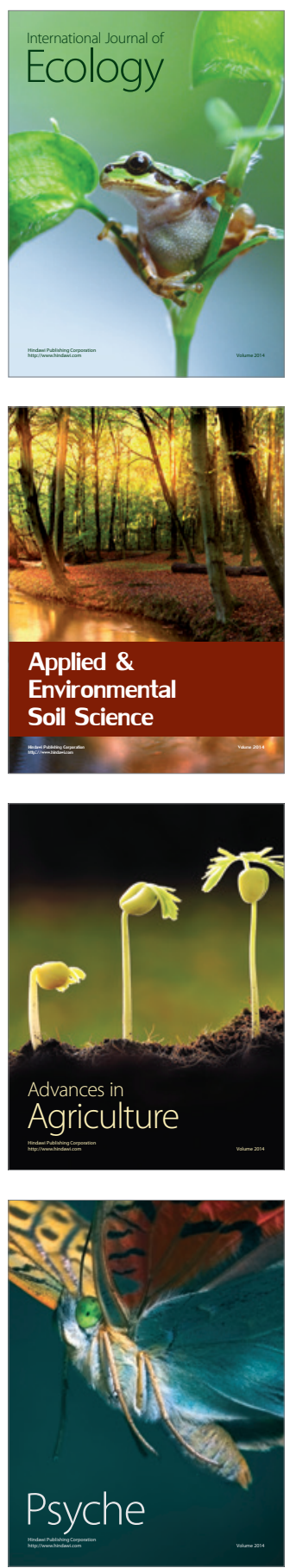